\title{
Investigation into the susceptibility of saithe Pollachius virens to infectious salmon anaemia virus (ISAV) and their potential role as a vector for viral transmission
}

\author{
M. Snow ${ }^{1, *}$, R. Raynard ${ }^{1}$, D. W. Bruno ${ }^{1}$, A. P. van Nieuwstadt ${ }^{2}$, N. J. Olesen ${ }^{3}$, \\ T. Løvold ${ }^{4}$, C. Wallace ${ }^{4}$ \\ ${ }^{1}$ Fisheries Research Series (FRS) Marine Laboratory, PO Box 101, Victoria Road, Aberdeen AB11 9DB, Scotland, UK \\ ${ }^{2}$ ID-Lelystad Institute for Animal Science and Health. PO Box 65, Lelystad 8200AB, The Netherlands \\ ${ }^{3}$ Danish Veterinary Laboratory, Department of Poultry, Fish and Fur Animals, Hangøvej 2, 8200 Aarhus, Denmark \\ ${ }^{4}$ Veterinærmedisinsk Oppdragssenter AS (VESO) Vikan Akvavet, Alhusstrand, 7800 Namsos, Norway
}

\begin{abstract}
Wild-caught saithe Pollachius virens were experimentally exposed to an isolate of infectious salmon anaemia virus (ISAV) of Norwegian origin. Mortality attributable to ISAV did not occur following exposure by intra-peritoneal (i.p.) injection of virus or by cohabitation with ISAV-infected Atlantic salmon Salmo salar. Despite the individual testing of 120 ISAV-exposed saithe, ISAV was not detectable using RT-PCR, the most sensitive ISAV diagnostic tool demonstrated to date. Furthermore, saithe exposed to ISAV-infected salmon were not capable of transmitting virus when transferred to tanks containing naïve salmon. Thus saithe appear to be resistant to this Norwegian isolate of ISAV and incapable of supporting its replication. Saithe which co-exist with salmon in and around aquaculture facilities are considered unlikely to have a significant impact on the epizootiology of ISAV.
\end{abstract}

KEY WORDS: Infectious salmon anaemia virus $\cdot$ ISAV $\cdot$ Orthomyxovirus $\cdot$ Saithe $\cdot$ Pollachius virens

\section{INTRODUCTION}

Infectious salmon anaemia (ISA) disease was first reported in Norway in 1984 (Thorud \& Djupvik 1988), and has since been responsible for considerable losses to cultured salmonids in Norway, Canada (Bouchard et al. 1999, Lovely et al. 1999), Scotland (Bricknell et al. 1998, Rodger et al. 1998, Stagg et al. 1999, Turnbull 1999), the US (Bouchard et al. 2001) and Chile (Kibenge et al. 2001). Findings based on molecular analyses indicate that North American isolates of ISAV may represent a distinct genomic variant from the Norwegian strains (Blake et al. 1999).

The specific origin of ISAV in Scotland remains similarly unclear. However, molecular analyses based on the nucleotide sequences of Segments 2 and 8 suggest

*E-mail: snowm@marlab.ac.uk that the Norwegian and Scottish isolates could belong to a common pool of ISAV (Stagg et al. 2001). The emergence of ISAV in Scotland could thus have resulted from accidental importation of ISAV from Norway via well-boat operations. Alternatively, a pathogenic form of ISAV may have emerged from a wild reservoir of virus at the site of the primary outbreak in Scotland (Stagg et al. 2001).

Norwegian research into ISAV has placed considerable emphasis on the identification of potential carrier species and their role as a vector for transmission of disease. In particular, brown trout Salmo trutta and rainbow trout have been shown to harbour ISAV virus, whilst not exhibiting clinical disease. Furthermore, these species have been shown to be capable of transmitting virus to Atlantic salmon in experimental challenges (Nylund \& Jakobsen 1995, Nylund et al. 1997). In addition, experimental infection studies have demonstrated the persistence of ISAV in Arctic char 
Salvelinus alpinus following intra-peritoneal infection, without the occurrence of clinical ISA disease (Snow et al. 2001). Thus, it is possible that all of these salmonid species could function as a reservoir for ISAV in areas where outbreaks of disease among cultured Atlantic salmon have been reported.

An additional candidate as a vector of ISAV is saithe Pollachius virens. Saithe are often found close to fishfarm cages, and young saithe can enter through the mesh of fish-net cages where they may grow rapidly (Bruno \& Stone 1990). Thus, if saithe could act as a carrier species for ISAV, they might represent an important vector for the spread of disease between wild and farmed fish. Indeed, saithe have been shown to play a potential role in the spread of sea lice Lepeoptheirus salmonis to Atlantic salmon (Bruno \& Stone 1990). Given the fact that $L$. salmonis have also been implicated in the transmission of ISAV (Nylund et al. 1993), the role of saithe as a potential reservoir for ISAV is an important issue to address. This study was thus designed to investigate the susceptibility of saithe to ISAV and to investigate their potential for transmission of ISAV to Atlantic salmon.

\section{MATERIALS AND METHODS}

Cell culture and virus propagation. The salmon head kidney (SHK-1) cell line was used for the isolation, propagation and identification of virus in this study, according to previously described methods (Dannevig et al. 1995). A Norwegian isolate of ISAV (Glesvaer/2/90) was used for experimental infections.
The isolate was kindly provided by the Veterinary Institute, Oslo, Norway (Passage 3 in SHK-1 cells).

Fish. Atlantic salmon were obtained from a commercial producer (Follasmolt AS; mean weight $64.1 \mathrm{~g}$ ). Saithe were wild caught in Norwegian waters with no history of ISAV in that area (mean weight $54 \mathrm{~g}$ ). Prior to commencing the experimental infection study, 10 fish of each species were individually screened for the presence of ISAV by RT-PCR assay (Mjaaland et al. 1997) and for the presence of ISAV, viral haemorrhagic septicaemia virus (VHSV), infectious haematopoietic necrosis virus (IHNV) and infectious pancreatic necrosis virus (IPNV) using previously described virological methods (Snow \& Smail 1999). Fishes were acclimated to $10^{\circ} \mathrm{C}$ for $7 \mathrm{~d}$, and the saithe weaned onto commercial salmon feed. Fishes were maintained at a stocking density of $<20 \mathrm{~kg} \mathrm{~m}^{-3}$ at 10 to $12^{\circ} \mathrm{C}$ in a total volume of $400 \mathrm{l}$, and supplied with $0.8 \mathrm{l}$ seawater $\mathrm{kg}^{-1}$ fish $\mathrm{min}^{-1}$.

Experimental infection of saithe and salmon with ISAV. Details of the treatment received by individual tanks are summarised in Fig. 1.

Phase I: Duplicate tanks were set up, each holding 70 salmon which were anaesthetised and i.p.-injected with $200 \mu \mathrm{l}$ ISAV representing an infectious dose of $2 \times 10^{2}$ TCID $_{50}$ fish $^{-1}$ (tissue culture infectious dose, Reed \& Muench 1938, Burleson et al. 1992; Tanks 1 and 2). A second set of duplicate tanks were set up, each holding 90 saithe which were anaesthetised and i.p.-injected with ISAV in the same manner (Tanks 5 and 6). Duplicate control tanks were also set up, each containing 70 saithe and 70 salmon which were injected with an equal volume $(200 \mu \mathrm{l})$ of phosphatebuffered saline (PBS) (Tanks 3 and 4).

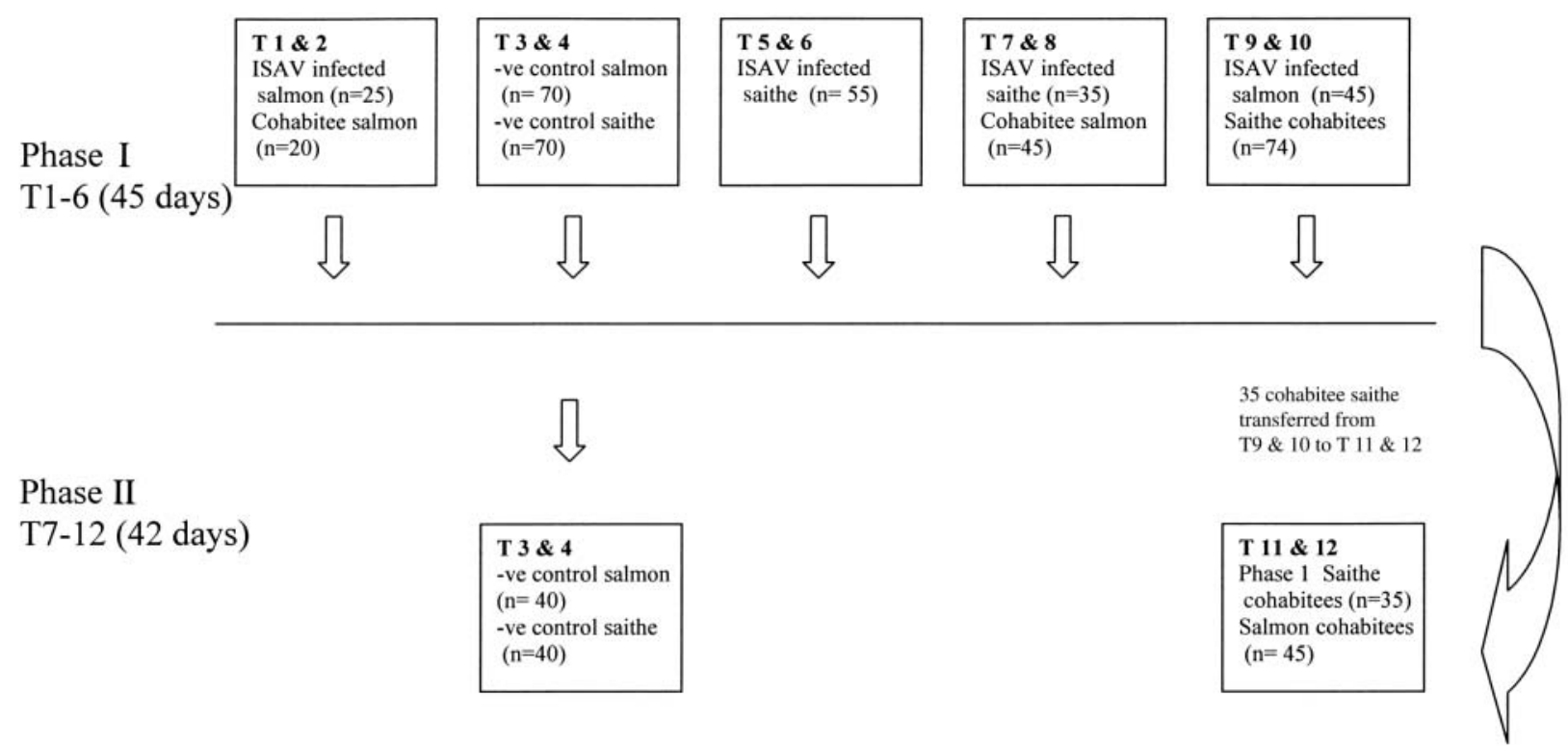

Fig. 1. Tank set-up for Phases I and II of the infection experiment. Numbers of fish of each species (salmon Salmo salar and saithe Pollachius virens) in each of the tanks (T1 to T12) at the start of each phase are shown in parentheses. -ve: negative 
Phase Ib: After 72 h, 35 saithe from each ISAVinfected tank (Tanks 5 and 6 ) were transferred to 2 further tanks each containing 45 naïve salmon to serve as cohabitees (Tanks 7 and 8). From each ISAV-infected tank (Tanks 1 and 2) 45 salmon were also transferred to 2 further tanks, each containing 74 naïve saithe to serve as cohabitees (Tanks 9 and 10). At this point, duplicate groups of 20 salmon were marked by cutting of the right maxilla and added to Tanks 1 and 2 . These fish were not sampled thoughout the experimental period, and served as positive controls to monitor the severity of the cohabitation infection.

Phase II: 43 d after setting up Phase I, 35 cohabiting saithe from Tanks 9 and 10 were transferred to new tanks containing 45 naïve salmon (Tanks 11 and 12). At the time of transfer, all remaining fish from Phase I with the exception of the negative control tanks (Tanks 3 and 4) were killed. Phase II fish were monitored for a period of $42 \mathrm{~d}$. Dead fish were collected daily and examined for gross pathological signs. The presence of bacteria in these fish was determined by plating kidney material on blood agar and blood agar with saline.

Sampling regime. Salmon or saithe were sacrificed and sampled from each of Tanks 3 to 10 at 7 d intervals for the duration of Phase Ib, according to the schedule detailed in Table 1 (T1-T6). Similarly, salmon from Tanks $3 \& 4$ and $11 \& 12$ were sampled at 7 d intervals throughout Phase II, as indicated in Table 1 (T7-T12).

Sampling methods. Kidney tissue was stored in $1 \mathrm{ml}$ RNALATER (Ambion) at $-20^{\circ} \mathrm{C}$ for RT-PCR, which was performed using previously described methods (Mjaaland et al. 1997). Kidney, liver, spleen and heart were sampled for virus culture on SHK-1 cells using previously described methods (Dannevig et al. 1995). Samples for RT-PCR and virus culture were processed from individual fish with the exception of negative controls (Tanks 3 and 4), which were processed as pools of tissue from 5 fish from the same tank and timepoint. Kidney, liver, spleen, heart, gut and pyloric caeca were fixed in $8 \%$ buffered formal saline, and sections were stained with haematoxylin and eosin (H\&E) for examination by light microscopy. Histological samples were coded and examined without knowledge of the fish species or treatment. Blood samples were taken from individual fish for haematocrit determination.

Statistical methods. Haematocrit values from ISAVinfected and control fish were compared statistically using a 2-tailed $t$-test, assuming unequal variance.

\section{RESULTS}

\section{Pathogen-testing of fishes}

Saithe and salmon were confirmed, by virological examination, to be free from VHSV, IHNV and IPNV prior to challenge. No evidence of ISAV infection was detectable following testing by RT-PCR.

\section{Experimental infection of saithe and salmon with ISAV}

The mortalities recorded in all tanks from which fish were periodically sampled for each $7 \mathrm{~d}$ period within Phases I and II of the trial are summarised in Table 2.

Table 1. Samples taken from experimental tanks throughout Phases I and II of the trial period. Five fish $(\mathrm{s}=\mathrm{salmon}$ Salmo salar; $\mathrm{p}=$ saithe Pollachius virens) were sampled from each tank at the timepoints detailed in 'Materials and methods' for viral detection by PCR (Pcr), virus culture (Vir), histological examination (His) and haematocrit determination (Ht). Control: duplicate control tanks with saithe and salmon injected with phosphate-buffered saline; i.p. saithe: saithe i.p.-injected with ISAV; i.p. saithe + salmon: i.p.-injected saithe transferred to tanks with naïve salmon as cohabitees; i.p. salmon + saithe: i.p.-injected salmon transferred to tanks with naïve saithe as cohabitees; cohabiting saithe + salmon: cohabiting saithe transferred to new tanks with naïve salmon

\begin{tabular}{|c|c|c|c|c|c|c|}
\hline \multirow[t]{3}{*}{ Timepoint } & \multirow{2}{*}{\multicolumn{2}{|c|}{$\begin{array}{c}\text { Control } \\
\text { Tanks } 3+4\end{array}$}} & \multirow{3}{*}{$\begin{array}{c}\text { i.p. saithe } \\
\text { Tanks } 5+6 \\
\text { p }\end{array}$} & \multirow{3}{*}{$\begin{array}{c}\text { i.p. saithe } \\
\text { + salmon } \\
\text { Tanks } 7+8 \\
\text { s }\end{array}$} & \multirow{3}{*}{$\begin{array}{c}\text { i.p. salmon } \\
\text { + saithe } \\
\text { Tanks } 9+10 \\
\text { p }\end{array}$} & \multirow{3}{*}{$\begin{array}{l}\text { Cohabiting saithe } \\
\text { + salmon } \\
\text { Tanks } 11+12 \\
\text { s }\end{array}$} \\
\hline & & & & & & \\
\hline & $\mathrm{s}$ & $\mathrm{p}$ & & & & \\
\hline $\mathrm{T} 1$ & Pcr Ht & Pcr Ht His & Pcr Ht His & Pcr Ht & Pcr Ht & - \\
\hline $\mathrm{T} 2$ & Pcr Ht & Pcr Ht His & Pcr Ht His & Pcr Ht & Pcr Ht & - \\
\hline T3 & Pcr Ht Vir & Pcr Ht His Vir & Pcr Ht His & Pcr Ht Vir & Pcr Ht Vir & - \\
\hline $\mathrm{T} 4$ & Pcr Ht & Pcr Ht His & Pcr Ht His & Pcr Ht & Pcr Ht & - \\
\hline T5 & Pcr Ht & Pcr Ht His & Pcr Ht His & Pcr Ht & Pcr Ht & - \\
\hline T6 & Pcr Ht Vir & Pcr Ht His Vir & Pcr Ht His & Pcr Ht Vir & Pcr Ht Vir & - \\
\hline $\mathrm{T} 7$ & Pcr & & & & & Pcr \\
\hline T8 & $\mathrm{Pcr}$ & & & & & Pcr \\
\hline T9 & $\mathrm{PCr}$ & & & & & $\mathrm{Pcr}$ \\
\hline T10 & Pcr Vir & & & & & Pcr Vir \\
\hline T11 & Pcr & & & & & Pcr \\
\hline T12 & Pcr & & & & & Pcr Vir \\
\hline
\end{tabular}


Phase I

Mortality recorded in positive control salmon infected with ISAV by i.p. injection or by cohabitation in Phase I, is detailed in Fig. 2. Mortality in the i.p.-infected fish commenced at $16 \mathrm{~d}$ post-infection, reaching cumulative totals of 82.9 and $88.6 \%$ in Tanks 1 and 2 by the end of Phase I (Fig. 2a). Mortality in cohabiting salmon commenced at 26 and 28 d post-infection in these tanks and reached final cumulative values of 70 and $55 \%$ respectively (Fig. 2a). Mortality in i.p. ISAV-infected salmon used to expose challenge saithe cohabitees to ISAV exhibited similar patterns of mortality, which commenced at 16 and $15 \mathrm{~d}$ post-infection and reached cumulative values of $100 \%$ in both replicates by $26 \mathrm{~d}$ post-infection (Tanks 9 and 10; Fig. 2b).

Ten cohabitee mortalities sampled from each of Tanks 1 and 2 all tested positive for ISAV by RT-PCR. Similarly, a further 32 fish mortalities occurring in i.p.-infected fish were sampled from Tanks $1 \& 2$ and Tanks $9 \& 10$ and all tested positive for ISAV. In addition, mortalities occurring in ISAV-exposed fish in these tanks all exhibited clinical pathology consistent with ISAV infection.

In the negative control tanks (Tanks 3 and 4), a total of 9 and 0 mortalities respectively were recorded in salmon following sham-injection with PBS (Table 2). In the case of negative control saithe, a single mortality occurred in Tank 4 only. All mortalities in negative control fish were tested by RT-PCR and proved negative for the presence of ISAV.

In Tanks 9 and 10, 6 and 5 mortalities respectively occurred in saithe cohabiting with ISAV-injected salmon during the same first-week period of Phase I (Table 2). However none of these mortalities occurred after $7 \mathrm{~d}$ post-infection, and all tested negative for ISAV by RT-PCR.

No mortality was recorded in replicates of saithe i.p.-infected with ISAV during Phase I (Tanks 5, 6, 7 and 8). In replicates of salmon cohabiting with saithe (Tanks 7 and 8), 10 and 1 mortalities were recorded respectively (Table 2). However, all of these fish tested negative for the presence of ISAV by RT-PCR.

\section{Phase 2}

In replicates of Tanks 11 and 12, 5 salmon mortalities were recorded during Phase II of the trial period. A single saithe mortality was also recorded in Tank 11 , and 2 salmon mortalities also occurred in 1 of the negative control replicates (Tank 12). However, all of these fish tested negative for the presence of ISAV by RT-PCR.
Table 2. Details of mortalities in tanks from which fishes (saithe Pollachius virens and salmon Salmo salmar) were removed for sampling. Percentage mortalities in each $7 \mathrm{~d}$ period in which mortality was recorded are expressed as a percentage of the fishes present in each tank at the start of each period. Treatments as in legend to Table 1

\begin{tabular}{|c|c|c|c|c|}
\hline $\begin{array}{l}\text { Treatment } \\
\text { Tank (species) }\end{array}$ & $\begin{array}{l}\text { Phase, } \\
\text { Timepoint }\end{array}$ & $\begin{array}{c}\text { Mortal- } \\
\text { ities }\end{array}$ & $\begin{array}{l}\text { No. in } \\
\text { tank }\end{array}$ & $\begin{array}{l}\% \text { mor- } \\
\text { tality }\end{array}$ \\
\hline \multicolumn{5}{|l|}{ Control } \\
\hline \multirow[t]{4}{*}{ Tank 3 (salmon) } & $\mathrm{I} \mathrm{T} 4$ & 1 & 55 & 1.8 \\
\hline & I T5 & 6 & 49 & 12.2 \\
\hline & I T6 & 2 & 38 & 5.3 \\
\hline & II T11 & 2 & 11 & 18.2 \\
\hline \multirow{2}{*}{ Tank 4 (saithe) } & I T1 & 1 & 70 & 1.4 \\
\hline & II T10 & 1 & 39 & 2.6 \\
\hline \multicolumn{5}{|l|}{ i.p. saithe + salmon } \\
\hline \multirow[t]{2}{*}{ Tank 7 (salmon) } & $\mathrm{I} \mathrm{T} 4$ & 9 & 30 & 30.0 \\
\hline & $\mathrm{I}$ T6 & 1 & 11 & 9.1 \\
\hline Tank 8 (saithe) & I T6 & 1 & 20 & 5.0 \\
\hline \multicolumn{5}{|l|}{ i.p. salmon + saithe } \\
\hline Tank 9 (saithe) & I T1 & 6 & 75 & 8.0 \\
\hline Tank 10 (saithe) & I T1 & 5 & 75 & 6.7 \\
\hline \multicolumn{5}{|c|}{ Cohabiting saithe + salmon } \\
\hline \multirow[t]{3}{*}{ Tank 11 (salmon) } & II T9 & 1 & 35 & 2.9 \\
\hline & II T10 & 3 & 29 & 10.3 \\
\hline & II T11 & 1 & 21 & 4.8 \\
\hline Tank 11 (saithe) & II T9 & 1 & 35 & 2.9 \\
\hline \multirow[t]{3}{*}{ Tank 12 (salmon) } & II T8 & 3 & 40 & 7.5 \\
\hline & II T10 & 1 & 27 & 3.7 \\
\hline & II T11 & 1 & 21 & 4.8 \\
\hline
\end{tabular}

\section{Sampling}

Despite the intensity of sampling, the presence of ISAV was not detectable by RT-PCR in any of the saithe sampled following i.p. injection with ISAV nor in saithe sampled following cohabitation with ISAV-infected salmon throughout the entire trial period. Similarly, the virus was not cultured from any saithe sampled during the trial, nor were any histological changes indicative of ISAV infection in saithe noted in any of the specimens. Also, salmon sampled for the presence of ISAV following cohabitation with i.p.-infected saithe (Tanks 7 and 8) in Phase I, and salmon cohabiting with ISAVexposed saithe (Tanks 11 and 12) all tested negative for ISAV by RT-PCR and virus culture.

\section{Haematocrit}

No significant change in the haematocrit was detected between groups of ISAV-exposed salmon or saithe with respect to control groups at Timepoints 1 to 5. At Timepoint 6 (42 d post-infection) however, the mean haematocrit in cohabiting salmon (Tanks 7 and 8) of $29.1 \pm 1.09 \mathrm{SE}$ was significantly lower $(p=0.009)$ 


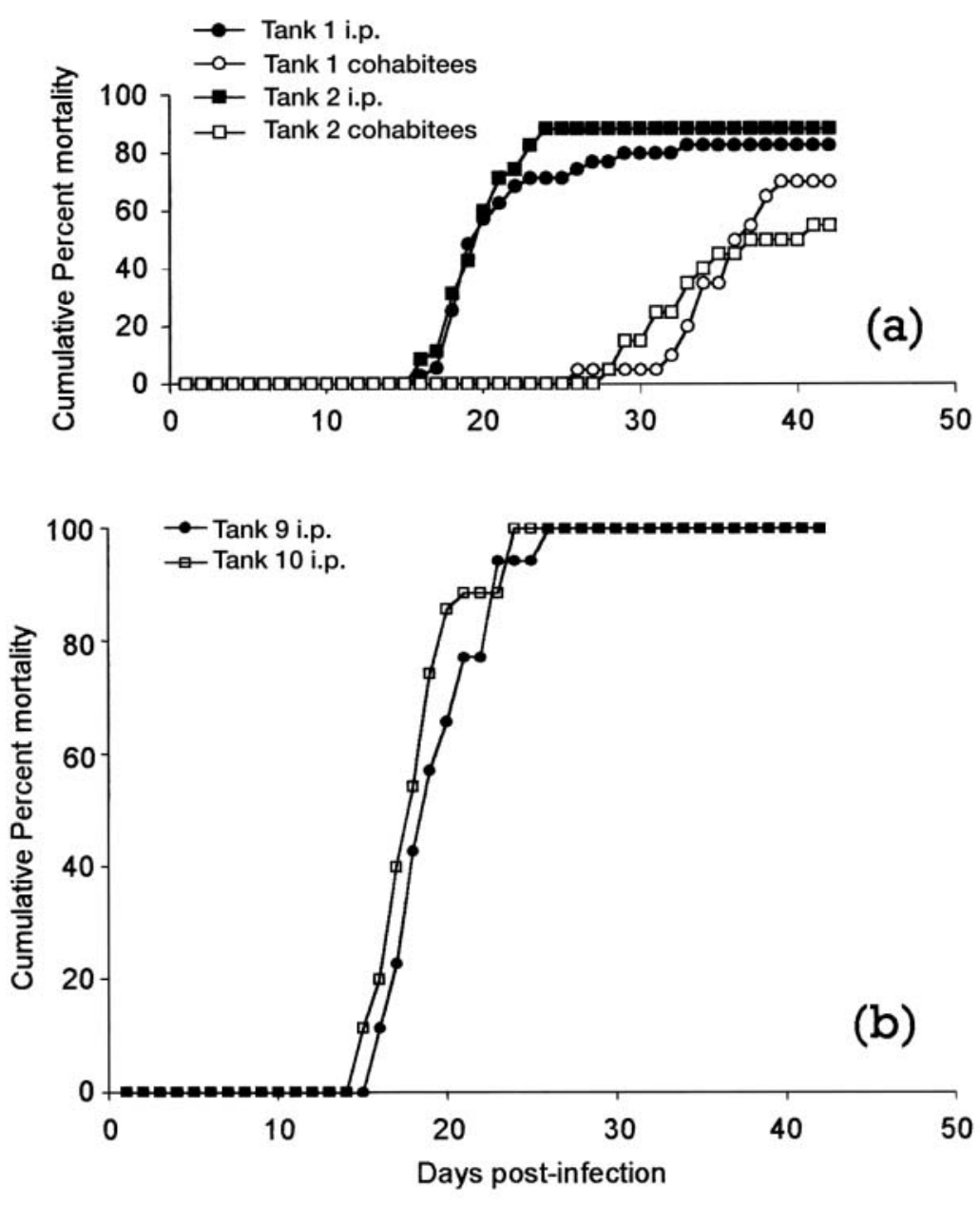

Fig. 2. Mortality data from (a) positive control salmon (Salmo salar) infected by i.p. injection or cohabitation (Tanks 1 and 2), and (b) salmon i.p.-infected with ISAV used to challenge cohabiting saithe (Pollachius virens, Tanks 9 and 10)

than that of the respective control group (34.9 \pm 1.64 SE; Tanks 3 and 4). Similarly at this timepoint, the mean haematocrit in i.p.-infected saithe (Tanks 9 and 10 ) of $28.6 \pm 0.73 \mathrm{SE}$ was also significantly lower $(p=0.003)$ than that of control groups $(31.6 \pm 0.45 \mathrm{SE}$; Tanks 3 and 4).

\section{DISCUSSION}

Mortality patterns in both i.p.-infected and cohabiting salmon in this study were in accordance with the models established by Raynard et al. (2001) for infection of salmon with a Scottish isolate of ISAV, and were, as expected, based on previous experience using the Norwegian isolate used in this trial. However, saithe were not susceptible to ISA disease following cohabitation or i.p. infection, the latter of which represents a severe challenge bypassing any natural resis- tance factors located on the surface of the fish (Nordmo 1997). Virus was not detectable from saithe at $1 \mathrm{wk}$ post-infection of fish infected with a large viral dose using RT-PCR, which is the most sensitive routine diagnostic tool for ISAV demonstrated to date (Devold et al. 2000). This test is not dependent on the presence of a complete virus, and these results thus suggest the elimination of the pathogen rather than the neutralisation of its infectivity.

A reduction in haematocrit has been used to demonstrate a host response to viral infection, indicative of viral replication in both sea trout Salmo trutta and rainbow trout Oncorhynchus mykiss, which have been identified as carrier species for ISAV (Nylund \& Jakobsen 1995, Nylund et al. 1997). A slight drop in the haematocrit was detected in positive controls of cohabiting salmon, in accordance with previous findings, indicative of ISAV replication. However, no change in the haematocrit was identifiable in saithe for $5 \mathrm{wk}$ following i.p. infection with ISAV. The slight drop recorded at $6 \mathrm{wk}$ post-infection is considered unlikely to have a significant physiological effect and as such may not be directly correlated to ISAV infection. This hypothesis is supported by the inability to detect the presence of ISAV in saithe following injection with the pathogen. Thus, it is unlikely that the isolate of ISAV used in this study has the capacity to replicate and elicit such a host response in saithe.

The mechanisms governing the susceptibility of different fish species to ISAV remains undetermined. Sea trout and rainbow trout are not susceptible to clinical ISA disease but develop into potentially life-long carriers of ISAV (Devold et al. 2000). In such cases, it has been postulated that most viral particles produced are probably neutralised within the host and are thus not infective (Devold et al. 2000). These particles still contain the genetic material required for detection of virus using diagnostic tests such as RT-PCR, which may account to some extent for the greater sensitivity of the RT-PCR assay compared to virus culture for ISAV. The development of such a carrier state for saithe has not been demonstrated using RT-PCR, however. Indeed, despite intensive sampling, no saithe tested during this trial were positive for ISAV by RT-PCR. Thus, the mechanisms of resistance to ISAV infection in saithe and salmonids may differ.

Enveloped viruses such as ISAV gain entry to host target cells by attachment to specific receptor mole- 
cules on the plasma membrane. Such cellular receptors are major determinants for the host range and tissue tropism of such viruses (Eliassen et al. 2000).

The inability of ISAV to replicate or persist in saithe following its introduction may be due to a failure of the virus to gain entry to permissive cell types and achieve initial infection. Interestingly, ISAV has been reported to display receptor-destroying activity on fish erythrocytes except for those of salmon (Eliassen et al. 2000). However, the role of cellular receptors in governing the entry of ISAV is not well understood. Alternatively, resistance to ISAV infection may be the result of cellmediated immunity, although the study of antiviral cytotoxic cells in fish remains in its early stages (Hogan et al. 1996).

In this study we have demonstrated the resistance of saithe to a Norwegian isolate of ISAV, in addition to their ability to rapidly clear the virus following experimental infection. Thus, the co-existence of saithe and salmon in salmon-culture facilities is unlikely to have a direct impact on the epizootiology of ISAV. However, the potential for saithe to harbour ISAV-infected sealice or other pathogens and thus re-infect salmon via an intermediate host remains.

\section{LITERATURE CITED}

Blake S, Bouchard D, Keleher W, Opitz M, Nicholson BL (1999) Genomic relationships of the North American isolate of infectious salmon anemia virus (ISAV) to the Norwegian strain of ISAV. Dis Aquat Org 35:139-144

Bouchard D, Keleher W, Opitz HM, Blake S, Edwards KC, Nicholson BL (1999) Isolation of infectious salmon anemia virus (ISAV) from Atlantic salmon in New Brunswick, Canada. Dis Aquat Org 35:131-137

Bouchard DA, Brockway K, Giray C, Keleher W, Merrill PL (2001) First report of infectious salmon anemia (ISA) in the United States. Bull Eur Assoc Fish Pathol 21:86-88

Bricknell IR, Bruno DW, Cunningham CO, Hastings TS, McVicar AH, Munro PD, Raynard RS, Stagg RM (1998) Report on the first occurrence of infectious salmon Anemia (ISA) in Atlantic salmon (Salmo salar) in Scotland, United Kingdom. In: Kane AS, Poynton SL (eds) Third International Symposium on Aquatic Animal Health, Baltimore, USA. APC Press, Baltimore, MD, p 132

Bruno DW, Stone J (1990) The role of saithe, Pollachius virens L., as a host for the sea lice, Lepeoptheirus salmonis Krøyer and Caligus elongatus Nordmann. Aquaculture 89: 210-207

Burleson FG, Chambers TM, Wiedbrauk DL (1992) Virology, a laboratory manual. Academic Press, San Diego, CA

Dannevig BH, Falk K, Namork E (1995) Isolation of the causal virus of infectious salmon anemia (ISA) in a long-term cell line from Atlantic salmon head kidney. J Gen Virol 76: 1353-1359

Devold M, Krossoy B, Aspehaug V, Nylund A (2000) Use of RT-PCR for diagnosis of infectious salmon anaemia virus (ISAV) in carrier sea trout Salmo trutta after experimental infection. Dis Aquat Org 40:9-18
Eliassen TM, Frøystad MK, Dannevig BH, Jankowska M, Brech A, Falk K, Romøren K, Gjøen T (2000) Initial events in infectious salmon anaemia virus infection: evidence for the requirement of a low-pH step. J Virol 74:218-227

Hogan RJ, Stuge TB, Clem LW, Miller NW, Chinchar VG (1996) Anti-viral cytotoxic cells in the channel catfish (Ictalurus punctatus). Dev Comp Immunol 20:115-127

Kibenge FSB, Gárate ON, Johnson G, Arriagada R, Kibenge MJT, Wadowska D (2001) Isolation and identification of infectious salmon anaemia virus (ISAV) from Coho salmon in Chile. Dis Aquat Org 45:9-18

Lovely JE, Dannevig BH, Falk K, Hutchin L, MacKinnon AM, Melville KJ, Rimstad E, Griffiths SG (1999) First identification of infectious salmon anaemia virus in North America with haemorrhagic kidney syndrome. Dis Aquat Org 35:145-148

Mjaaland S, Rimstad E, Falk K, Dannevig BH (1997) Genomic characterization of the virus causing infectious salmon anemia in Atlantic salmon (Salmo salar L.): an orthomyxolike virus in a teleost. J Virol 71:7681-7686

Nordmo R (1997) Strengths and weaknesses of different challenge methods. In: Gudding R, Lillehaug A, Midtlyng PJ, Brown F (eds) Fish vaccinology. Karger, Basel

Nylund A, Jakobsen P (1995) Sea Trout as a carrier of infectious salmon anaemia virus. J Fish Biol 47:174-176

Nylund A, Wallace C, Hovland T (1993) The possible role of Lepeophtheirus salmonis (Krøyer) in the transmission of infectious salmon anaemia. In: Boxshall G, Defaye D (eds) Pathogens of wild and farmed fish: sea lice. Ellis Horwood, London

Nylund A, Kvenseth AM, Krossoy B, Hodneland K (1997) Replication of the infectious salmon anaemia virus (ISAV) in rainbow trout, Oncorhynchus mykiss (Walbaum). J Fish Dis 20:275-279

Raynard RS, Snow M, Bruno DW (2001) Experimental infection models and susceptibility of Atlantic salmon (Salmo salar) to a Scottish isolate of infectious salmon anaemia virus. Dis Aquat Org 47:169-174

Reed LJ, Muench H (1938) A simple method of estimating fifty percent endpoints. Am J Hyg 27:493-497

Rodger HD, Turnbull T, Muir F, Millar S, Richards RH (1998) Infectious salmon anaemia (ISA) in the United Kingdom. Bull Eur Assoc Fish Pathol 18:115-116

Snow M, Smail DA (1999) Experimental susceptibility of turbot Scophthalmus maximus to viral haemorrhagic septicaemia virus isoloted from cultivated turbot. Dis Aquat Org 38:163-168

Snow M, Raynard RS, Bruno DW (2001) Comparative susceptibility of arctic char (Salvelinus alpinus), rainbow trout (Oncorhynchus mykiss) and brown trout (Salmo trutta) to the Scottish isolate of infectious salmon anaemia virus. Aquaculture 196:47-54

Stagg R, Bruno D, Cunningham C, Hastings T, Bricknell I (1999) Focus on infectious salmon anaemia: epizootiology and pathology. State Vet J 9:1-5

Stagg RM, Bruno DW, Cunningham CO, Raynard RS and 6 others (2001) Epizootiological investigations into an outbreak of infectious salmon anaemia (ISA) in Scotland. FRS Marine Laboratory Report No 13/01, Fisheries Research Services, Marine Laboratory, Aberdeen

Thorud K, Djupvik HO (1988) Infectious anaemia in Atlantic salmon (Salmo salar L.). Bull Eur Assoc Fish Pathol 8: 109-111

Turnbull T (1999) Infectious salmon anaemia in the United Kingdom. Fish Vet J 3:64-67

Submitted: August 31, 2001; Accepted: December 20, 2001

Proofs received from author(s): June 14, 2002 